\title{
1 mRNA Degradation Rates Are Coupled to Metabolic Status in Mycobacteria
}

3 Diego A. Vargas-Blanco ${ }^{\text {a }}$ Ying Zhou ${ }^{\mathrm{a}}$, Luis Gutierrez Zamalloa ${ }^{\mathrm{a}}$, Tim Antonelli ${ }^{\mathrm{b}}$, Scarlet S.

$4 \quad$ Shell ${ }^{\mathrm{a}, \mathrm{c}^{*}}$

5

$6{ }^{a}$ Department of Biology and Biotechnology, Worcester Polytechnic Institute, Worcester,

7 Massachusetts, USA

$8{ }^{\mathrm{b}}$ Department of Mathematics, Worcester State University, Worcester, Massachusetts, USA

$9{ }^{\mathrm{c}}$ Program in Bioinformatics and Computational Biology, Worcester Polytechnic Institute,

10 Worcester, Massachusetts, USA

$12 \quad$ *Address correspondence to Scarlet S. Shell, sshell@wpi.edu.

Keywords: ATP, carbon starvation, hypoxia, mRNA degradation, mRNA stability, Mycobacterium smegmatis, stress response, tuberculosis.

The success of Mycobacterium tuberculosis (Mtb) as a human pathogen is due in part to its ability to survive stress conditions, such as hypoxia or nutrient deprivation, by entering non- 
21 genetically encoded antibiotic resistance, making its metabolic adaptation to stress crucial for

22 survival. Numerous bacteria, including Mtb, have been shown to reduce their rates of mRNA

23 degradation under growth limitation and stress. While the existence of this response appears to

24 be conserved across species, the underlying bacterial mRNA stabilization mechanisms remains unknown. To better understand the biology of non-growing mycobacteria, we sought to identify the mechanisms by which mRNA stabilization occurs using the non-pathogenic model Mycobacterium smegmatis. We found that mRNA half-life was responsive to energy stress, with carbon starvation and hypoxia causing global mRNA stabilization. This global mRNA stabilization was rapidly reversed when hypoxia-adapted cultures were re-exposed to oxygen, even in the absence of new transcription. The stringent response and RNase protein levels did not explain mRNA stabilization, nor did transcript abundance. This led us to hypothesize that metabolic changes during growth cessation impact the activity of degradation proteins,

33 increasing mRNA stability. Indeed, bedaquiline and isoniazid, two drugs with opposing effects on cellular energy status, had opposite effects on mRNA half-lives in growth-arrested cells. Taken together, our results indicate that mRNA stability in mycobacteria is not directly regulated by growth status, but rather seems to be dependent on the status of energy metabolism.

\section{IMPORTANCE}

The logistics of treating tuberculosis are difficult, requiring multiple drugs for at least six months. Mtb is able to survive within the human host in part by entering non-growing states in which it is metabolically less active, thus rendering it less susceptible to antibiotics. Basic

41 knowledge on how Mtb survives during these low-metabolic states is incomplete, and we

42 postulate that optimized energy resource management - such as transcriptome stabilization-is

43 important for survival. Here we report that mRNA stabilization (increased mRNA half-lives) is a 
44 common feature of mycobacteria under stress (e.g. hypoxia and nutrient deprivation) but is not

45 dependent on the mechanisms that have been most often postulated in the literature. Finally, we

46 found that mRNA stability and growth status can be decoupled by a drug that causes growth

47 arrest but increases metabolic activity, indicating that mRNA stability responds to metabolic

48 status rather than to growth rate changes per se. Our findings suggest a need to re-orient the

49 study of global mRNA stabilization to identify novel mechanisms that are presumably

50 responsible.

51

52 INTRODUCTION

53 Most bacteria periodically face environmental conditions that are unfavorable for growth. To

54 overcome such challenges, bacteria must adapt both their gene expression profiles and their

55 energy usage. Regulation of mRNA turnover can contribute to both of these. However, the

56 mechanisms by which mRNA turnover is carried out and regulated remain poorly understood,

57 particularly in mycobacteria.

58 During infection, the human pathogen Mycobacterium tuberculosis (Mtb) faces not only the

59 immune response and antibiotics, but also multiple non-optimal microenvironments, such as

60 hypoxia and nutrient starvation within the granuloma $(1,2)$. Regulation of mRNA turnover

61 appears to contribute to adaptation to such conditions. A global study of mRNA decay in Mtb

62 showed a dramatic increase in transcriptome stability — measured as increased mRNA half-

63 lives - in response to hypoxia, when compared to log phase growth in oxygen-rich conditions

64 (3). This suggests that mRNA stabilization is important for energy conservation in the energy-

65 limited environments that Mtb encounters during infection. Similar responses have been shown 
for other bacteria under stress conditions that slow or halt growth, including carbon deprivation, stationary phase, and temperature shock (4-13). However, the mechanisms responsible for global regulation of mRNA stability in prokaryotes have yet to be elucidated. involved in mRNA processing and decay are RNase E and RNase Y, respectively. A

71 conventional model for RNA decay in E. coli start with an endonucleolytic cleavage event

72 usually carried by RNase E in AU-rich regions, particularly in mRNA substrates that possess a 5'

73 monophosphate (14-16). The resulting 5' monophosphorylated fragments are rapidly cleaved by

74 RNase E, resulting in shorter fragments that can be fully degraded by exonucleases such as

75 PNPase, RNase II, and RNase R $(17,18)$. mRNA degradation seems to be coordinated by

76 formation of a complex known as the degradosome. In E. coli, RNase E serves as the scaffold for

77 this multiprotein complex that comprises RNA helicases, the glycolytic enzyme enolase, and

78 PNPase (19-23). Other organisms that encode RNase E form similar degradosomes (24, 25). In

79 organisms where RNase $\mathrm{E}$ is not present, RNase $\mathrm{Y}$ and/or RNase $\mathrm{J}$ seem to assume the scaffold

80 function (26-28). Mycobacteria encode RNase E, but efforts to define the mycobacterial

81 degradosome have produced inconsistent results $(29,30)$. It is unclear if degradosome

82 reorganization or dissolution contribute to the global regulation of mRNA degradation under

83 stress conditions in any bacteria. Interestingly, the importance of degradosome formation in $E$.

84 coli varies depending on the carbon sources provided, suggesting specific links between RNase E

85 degradosomes and metabolic capabilities (31). Furthermore, the chaperones DnaK and CsdA can

86 become degradosome components in E. coli under certain stresses $(20,32,33)$.

87 Global transcript stabilization in stressed bacteria could plausibly result from reduced RNase abundance, reduced RNase activity, and/or reduced accessibility of transcripts to degradation 
proteins. In E. coli it has been shown that multiple stressors can upregulate RNase R, possibly as

90

91

92 a way to overcome ribosome misassembly $(34,35)$, and that RNase III levels decrease under cold-shock and stationary phase (36). Surprisingly, protein levels for most putative RNA degradation proteins in $M$. tuberculosis remain unaltered under hypoxic conditions (37), which suggests that mRNA degradation is not necessarily regulated at the level of RNase abundance in mycobacteria. However, there is evidence that RNase activity may be regulated. For example, proteins such as RraA and RraB can alter the function of the RNase E-based degradosome in $E$. coli (38). Translating ribosomes can mask mRNA cleavage sites, and, indeed, transcriptiontranslation dissociation experiments showed that ribosome-free mRNAs were highly unstable (39). Furthermore, in some actinomycetes PNPase might be regulated by the stringent response alarmone guanosine tetraphosphate (ppGpp) (40, 41). In Gram-negative bacteria ppGpp is usually synthesized by RelA, which is activated in the presence of uncharged tRNAs, or by the ppGpp synthase/hydrolase SpoT during fatty acid starvation (42). In Gram-positive bacteria, ppGpp is commonly synthesized by a dual RelA/SpoT homolog (43-45). Diverse bacteria adapt to stress using ppGpp in different pathways, which generally result in halting the synthesis of stable RNA (tRNAs and rRNAs), while upregulating stress-associated genes and downregulating those associated with cell growth (45-50). Recent reports in two actinomycetes -Streptomyces coelicolor and Nonomuraea — showed that, at physiological levels, ppGpp inhibited the enzymatic activity of PNPase (40,41), suggesting that the stringent response could directly stabilize mRNA as part of a broader response to energy starvation.

Another explanation for stress-induced transcript stabilization could be that reduced transcript abundance directly leads to increased transcript stability. mRNA abundance and half-life were reported to be inversely correlated in multiple bacteria including Mtb $(3,8,51,52)$, and mRNA 
112 abundance is lower on a per-cell basis for most transcripts in non-growing bacteria. In

113 Caulobacter crescentus, subcellular localization of mRNA degradation proteins may play a role

114 in global mRNA stability $(53,54)$. Nevertheless, the causal relationships between translation,

115 mRNA abundance, RNase expression, and mRNA stability in non-growing bacteria remain

116 largely untested.

117 Given the importance of adaptation to energy starvation for mycobacteria, we sought to

118 investigate the mechanisms by which mRNA stability is globally regulated. Here we show that

119 the global mRNA stabilization response occurs also in Mycobacterium smegmatis - a non-

120 pathogenic model commonly used to study the basic biology of mycobacteria - under hypoxia

121 and carbon starvation. We found that hypoxia-induced mRNA stability is rapidly reversible, with

122 re-aeration causing immediate mRNA destabilization even in the absence of protein synthesis.

123 As expected, we found that transcript levels from hypoxic cells are lower on a per-cell basis

124 compared to those from aerated cultures. However, our data are inconsistent with a model in

125 which mRNA abundance dictates degradation rate as has been shown for log-phase E. coli (51)

126 and Lactococcus lactis (52). Instead, our findings support the idea that mRNA stability is rapidly

127 tuned in response to alterations in energy metabolism. This effect does not require the stringent

128 response or changes in abundance of RNA degradation proteins, and it can be decoupled from

129 growth status. 


\section{RESULTS}

133

134

\section{mRNA is stabilized as a response to carbon starvation and hypoxic stress in Mycobacterium}

\section{smegmatis}

The mRNA pools of $E$. coli and other well-studied bacteria were reported to be globally stabilized during conditions of stress, resulting in increased mRNA half-lives (3-13). In 2013, Rustad et al. reported a similar phenomenon in Mtb under hypoxia and during cold shock (3). We sought to establish $M$. smegmatis as a model for study of the mechanistic basis of mRNA stabilization in mycobacteria under stress conditions. We therefore subjected $M$. smegmatis to hypoxic and carbon starvation stresses, and measured mRNA half-lives for a subset of genes by blocking transcription with rifampicin (RIF) and measuring mRNA abundance at multiple time points using quantitative PCR (qPCR). Indeed, we observed that all of the analyzed transcripts had increased half-lives under hypoxia when compared to log phase normoxic cultures and, similarly, transcripts were more stable in carbon starvation than in rich media (Fig. 1A and 1B).

Thus, M. smegmatis appears to be a suitable model organism for investigating the mechanisms of stress-induced mRNA stabilization in mycobacteria. We used a variation of the Wayne model (55) to produce a gradual transition from aerated growth to hypoxia-induced growth arrest by sealing cultures in vials with defined headspace ratios and allowing them to slowly deplete the available oxygen (Fig. 1C). We noted that transcripts became progressively more stable as oxygen levels dropped and growth ceased; 40 hours after sealing the vials, mRNA half-lives were too long to reliably measure by our methodology. We sought to focus our studies on the mechanisms that underlie the initial mRNA stabilization process during the transition into hypoxia-induced growth arrest. We therefore conducted subsequent experiments 18 hours after 
154

155

sealing the vials, when growth had nearly ceased and transcripts were 9-fold to 25-fold more stable than during log phase growth. We hereafter refer to this condition as $18 \mathrm{~h}$ hypoxia.

\section{ppGpp does not contribute to mRNA stabilization in hypoxia or carbon starvation}

Given recent reports that ppGpp could directly inhibit the enzymatic activity of PNPase $(40,41)$, we wondered whether mRNA stabilization as observed in carbon starvation and hypoxia is regulated by ppGpp in mycobacteria. We obtained a double mutant strain of $M$. smegmatis (56) that lacks both genes implicated in the production of ppGpp ( $\Delta r e l \Delta s a s 2)$, and compared the mRNA half-lives of a subset of genes to those of wild type $\mathrm{mc}^{2} 155$ under hypoxia, $\log$ phase normoxia, and carbon starvation conditions. The $\Delta$ rel $\Delta s a s 2$ strain had a modest growth defect during adaptation to hypoxia and carbon starvation (Fig. 2A and 2C), as predicted (57). However, we found no significant decrease in mRNA stabilization in the mutant strain (Fig. 2B and 2D), indicating that the mRNA stabilization we observed under hypoxia and carbon starvation is independent from the stringent response. Interestingly, the mutant strain displayed increased mRNA stabilization for a few transcripts under carbon starvation conditions, which could be an indirect consequence of altered transcription rates (see discussion).

\section{Hypoxia-induced mRNA stability is reversible and independent of mRNA abundance}

We wondered if the observed stress-induced transcript stabilization could be easily reversed by restoration of a favorable growth environment. To test this, we prepared $18 \mathrm{~h}$ hypoxia cultures, then opened the vials and agitated them for 2 min to re-expose the bacteria to oxygen before blocking transcription with RIF and sampling thereafter (Fig. 3A, top panel). We found that, for all transcripts tested, half-lives were significantly decreased compared to those observed under hypoxia and similar to those observed in log phase normoxia (Fig. 3B). While the mechanisms of 
stress-induced mRNA stabilization are largely unknown, multiple studies have reported inverse correlations between mRNA abundance and half-life in bacteria $(3,8,51,52)$. mRNA abundance is decreased for most transcripts tested in hypoxia-adapted $M$. smegmatis. We therefore considered the possibility that the dramatic increase in mRNA degradation upon re-exposure to oxygen was triggered by a rapid burst of transcription. Indeed, we found increased expression levels for three of five genes tested after two minutes of re-aeration, showing that transcription is rapidly induced upon return to a favorable environment (Fig. 3C). To test the idea that mRNA is destabilized by re-aeration as a consequence of a transcriptional burst and/or increased mRNA abundance, we modified our re-aeration experiment by blocking transcription with RIF one minute prior to re-exposure to oxygen (Fig. 3A, bottom panel). Surprisingly, every transcript tested was destabilized by the presence of oxygen despite the absence of new transcription. For most transcripts, the re-aeration half-lives were indistinguishable regardless of whether RIF was added prior to opening the vials or two minutes after (Fig. 3B). Our results therefore do not support the idea that changes in mRNA abundance alone can explain the mRNA stabilization and destabilization observed in response to changes in energy status.

We wanted to further explore if mRNA abundance alone could influence transcript degradation. Hence, we obtained a $M$. smegmatis strain encoding $d \operatorname{Cas} 9$ and a non-specific sgRNA under control of an ATc-inducible promoter (58) and compared the dCas 9 transcript stability under hypoxia and $\log$ phase normoxic conditions after ATc induction or at basal levels of expression. Our results showed that despite a 34-fold transcript upregulation following ATc induction, the half-life of $d \operatorname{Cas} 9$ mRNA was not significantly different from the no-drug control under log phase normoxia. Under hypoxia, its 28-fold upregulation was associated with a modest increase in $d \operatorname{Cas} 9$ mRNA half-life when compared to the no-drug control (Fig. 3D and 3E). Taken 
199

200

201

202

203

204

205

206

207

208

209

210

211

212

213

214

215

216

217

218

219

220

221

together, our results show that increased mRNA abundance does not necessarily result in a faster decay rate.

\section{mRNA stability is modulated independently of RNase protein levels}

Another potential explanation for increased mRNA degradation after re-aeration is the upregulation of mRNA degradation proteins such as RNase E. To assess the role of a sudden burst in protein levels we used two approaches. First, we constructed $M$. smegmatis strains encoding FLAG-tagged RNase E, cMyc-tagged PNPase, or cMyc-tagged predicted RNA helicase msmeg_1930. PNPase is an essential exoribonuclease. We determined protein levels by western blotting during log phase, in $18 \mathrm{~h}$ hypoxia, and after $18 \mathrm{~h}$ hypoxia followed by 2 min re-aeration. As shown in Fig. 4A, levels of all three of these predicted RNA degradation proteins remained unchanged in the three conditions.

Because we do not know all of the proteins that contribute to mRNA degradation in mycobacteria, our second approach was to test the global importance of translation in reaeration-induced mRNA destabilization. We blocked translation with chloramphenicol (CAM) in $18 \mathrm{~h}$ hypoxia cultures and then added RIF. Samples were collected for cultures that remained under hypoxia as well as those that were re-exposed to oxygen for $2 \mathrm{~min}$ (Fig. 4B). Our results showed that there is destabilization of mRNA after re-aeration even in the absence of protein synthesis (Fig. 4C), though not to the extent we observed in Fig. 3B. These results suggest that re-aeration-induced destabilization does not require synthesis of new RNA degradation proteins.

The mRNA stabilization induced by CAM itself is likely related to its mechanism of action.

CAM inhibits elongation by blocking the $50 \mathrm{~S}$ ribosomal subunit from binding tRNAs, preventing peptidyl transferase activity (59-61) and causing ribosomal stalling (62). Thus, consistent with our data, others have reported global stabilization of mRNA pools when 
222 elongation inhibitors, but not initiation inhibitors, are used for example in log phase cultures of

223 E. coli (62) or in yeast (63). We hypothesize that stalled ribosomes may increase mRNA stability

224 by masking RNase cleavage sites. However, we observe mRNA destabilization in response to re-

225 aeration despite this effect (Fig. 4C). Taken together, our data suggest that tuning of protein

226 levels is not the primary explanation for mRNA stabilization during early adaptation to hypoxia.

\section{7 mRNA stability is modulated in response to changes in metabolic status}

228 The rapidity of mRNA destabilization in response to re-aeration suggested that mRNA

229 degradation is tightly regulated in response to changes in energy metabolism. We tested this

230 hypothesis by treating $\log$ phase cultures of $M$. smegmatis with $5 \mu \mathrm{g} \cdot \mathrm{mL}^{-1}$ bedaquiline (BDQ), a

231 potent inhibitor of the ATP synthase F0F1 (64). We used minimal media that contained acetate

232 as the only carbon source (MMA) in order to make the respiratory chain the sole source of ATP

233 synthesis. After 30 min exposure, intracellular ATP levels were reduced by more than $90 \%$ in

234 BDQ-treated cells, when compared to cells treated with the drug vehicle (DMSO), without

235 affecting cell viability (Fig. 5A and 5B). We then measured half-lives for a set of transcripts

236 under these conditions. mRNA half-lives were dramatically increased in BDQ-treated cells for

237 most of the genes we tested (Fig. 5C), indicating that mRNA degradation rates are rapidly altered

238 in response to changes in energy metabolism status.

239 We then wondered if we could increase mRNA degradation rates by increasing intracellular ATP

240 levels. To test this, we treated M. smegmatis cultures with isoniazid (INH) a pro-drug that

241 interferes with the synthesis of mycolic acids, but that also leads to an accumulation of

242 intracellular ATP due to increased oxidative phosphorylation (65). We exposed M. smegmatis to

$243500 \mu \mathrm{g} \cdot \mathrm{mL}^{-1} \mathrm{INH}$ for 6.5 hours to confirm that we had achieved bacteriostasis (the M. smegmatis

244 doubling time in MMA media is approximately six hours). As shown in Fig. 5D, INH caused a 
245 dramatic increase in intracellular ATP after $6.5 \mathrm{~h}$ without affecting cell viability (Fig. 5E).

246 Remarkably, mRNA half-lives were significantly decreased in response to INH (Fig. 5F). To our

247 knowledge, this is the first report of bacterial mRNA being destabilized rather than stabilized in

248 response to a growth-impairing stressor. Our results indicate that mRNA stability is regulated not

249 in response to growth status per se, but rather to energy metabolism. Although we interpreted

250 ATP levels as a reflection of metabolic status in our INH and BDQ assays, the coupling between

251 mRNA degradation and metabolic status does not appear to be mediated by ATP directly. We

252 measured ATP levels in M. smegmatis cultures during the transition to hypoxia-induced growth

253 arrest, and found that although ATP levels ultimately decrease in hypoxia as has been reported

254 elsewhere $(66,67)$, mRNA stabilization precedes the drop in ATP levels (Fig. 5G).

\section{DISCUSSION}

257 Many stressors cause bacteria to slow or stop growth, and this is usually associated with

258 increased mRNA stability (3-9, 11-13). Many of these same stressors reduce energy availability

$259(66,67)$, requiring reductions in energy consumption and optimization of resource allocation. We

260 speculate that the decreased mRNA turnover that accompanies such conditions may be an energy

261 conservation mechanism. For Mtb, hypoxia can lead to generation of bacterial subpopulations

262 with varying degrees of antibiotic tolerance (68-70), facilitating bacterial survival and the

263 acquisition of drug resistance-conferring mutations. Understanding the mechanisms that support

264 the transitions into non-growing states, and subsequent survival in these states, is therefore of

265 great importance. 
266 The transcriptome of Mtb has been previously shown to be stabilized under cold shock and

267 hypoxia (3). Here, we found that M. smegmatis also dramatically stabilized its mRNA in

268 response to carbon starvation and oxygen depletion. For the first time, to our knowledge, we

269 tested the speed at which this stabilization is reversed in mycobacteria upon restoration of energy

270 availability. Remarkably, mRNAs are rapidly destabilized within minutes of re-aeration of

271 hypoxic cultures, suggesting that tuning of mRNA degradation rates is an early step in the

272 response to changing energy environments.

273 The most straightforward explanation for stress-induced mRNA stabilization would seem to be

274 downregulation of the mRNA degradation machinery. Indeed, under hypoxic conditions, RNase

275 E is downregulated at the transcript level, and abundance of cleaved RNAs is notably reduced

276 (71). However, we found that protein levels were unchanged for three proteins predicted to be

277 core components of the mRNA degradation machinery. This is largely consistent with what was

278 reported for Mtb in a quantitative proteomics study (37), although in that case there was an

279 apparent reduction in levels of a predicted RNA helicase. To address this question in a more

280 agnostic fashion, we tested the importance of translation for transcript destabilization upon re-

281 exposure of hypoxic cultures to oxygen. However, re-aeration triggered increased transcript

282 degradation even in the absence of new protein synthesis. Regulation of degradation protein

283 levels therefore does not appear to contribute to mRNA stabilization during the initial response

284 to energy stress. However, we found that upon longer periods of hypoxia, transcripts were

285 stabilized to a greater extent than what we observed 18 hours after sealing the vials. This

286 suggests that mRNA stabilization progressively increases, and may be the product of multiple

287 mechanisms. As this work focused on the initial transition into hypoxia-induced growth arrest, 
we cannot discount the possibility that downregulation of the RNA degradation machinery is important for further mRNA stabilization in later hypoxia stages.

Interestingly, we found greater mRNA stabilization in hypoxic cultures treated with CAM. This may result from stalled ribosomes $(59,61)$ masking RNase cleavage sites. Furthermore, the burst

292 of transcription upon re-aeration is blocked by the presence of CAM, causing up to a four-fold 293 decrease in transcript abundance in the CAM treated cultures when compared to the vehicle 294 treated cultures. This is consistent with the idea that transcription and translation are physically 295 coupled, and blocking translation therefore prevents RNA polymerase from efficiently carrying 296 out transcript elongation, as has been reported for E. coli (72-76).

297 Transcript abundance has been found to be inversely correlated with mRNA stability in exponentially growing bacteria $(3,8,51,52,77)$, and experimental manipulation of transcription 299 rates of subsets of genes resulted in altered degradation rates $(3,52)$. Together, these studies suggest that high rates of transcription inherently increase degradation rates. We report here that

301 during oxygen depletion transcript levels are reduced in $M$. smegmatis, which led us to ask if increased transcript half-lives under stress are a direct result of reduced mRNA levels. However, our data are inconsistent with this idea; mRNA is rapidly destabilized upon re-aeration even in 304 the absence of new transcription. We note that one study reported a weak positive correlation 305 between mRNA abundance and stability in log phase E. coli (12), while another reported mRNA 306 abundance to be positively correlated with stability in carbon-starved Lactococcus lactis (8).

307 Taken together, these observations and our own suggest that the relationship between mRNA 308 stability and abundance is not yet fully understood and may be fundamentally different in 309 growth-arrested bacteria. 
The rapid reversibility of hypoxia-induced mRNA stabilization suggests that mRNA decay and

311

312

313

314

315

316

317

318

319 energy metabolic status are closely linked. Consistent with this idea, we have shown that druginduced energy stress causes mRNAs to be stabilized, while mRNA decay is increased by a drug that induces a hyperactive metabolic state. To our knowledge this is the first demonstration that the rate of bacterial mRNA degradation can be decoupled from growth rate, and suggests that mRNA decay is controlled by energy status rather than growth rate per se. The mechanism by which energy status and mRNA decay are coupled remains elusive; the stringent response is not required, and the stabilization of mRNA during adaptation to hypoxia precedes a decrease in ATP levels. Possible explanations that should be investigated in future work include ribosome occupancy, the presence of other RNA-binding proteins, and the subcellular localization of mRNAs and the RNA degradation machinery.

\section{METHODS}

\section{Strain and culture conditions}

Mycobacterium smegmatis strain $\mathrm{mc}^{2} 155$ or derivatives (Table 1) were grown in rich medium, Middlebrook 7H9 supplemented with ADC (Albumin Dextrose Catalase, final concentrations 5 $\mathrm{g} \cdot \mathrm{L}^{-1}$ bovine serum albumin fraction $\mathrm{V}, 2 \mathrm{~g} \cdot \mathrm{L}^{-1}$ dextrose, $0.85 \mathrm{~g} \cdot \mathrm{L}^{-1} \mathrm{NaCl}$, and $3 \mathrm{mg} \cdot \mathrm{L}^{-1}$ catalase), $0.2 \%$ glycerol and $0.05 \%$ Tween 80 at $200 \mathrm{rpm}$ and $37^{\circ} \mathrm{C}$ to an $\mathrm{OD}_{600}$ of $\sim 0.8$, unless specified otherwise. For the hypoxic cultures, we used a modification of the Wayne model (55). Briefly, M. smegmatis was cultured in 30.5 x $58 \mathrm{~mm}$ serum bottles (Wheaton, 223687, $20 \mathrm{~mL}$ ) using rich medium and an initial $\mathrm{OD}_{600}=0.01$. The bottles were sealed with a vial crimper (Wheaton, W225303) using rubber stoppers (Wheaton, W224100-181) and aluminum seals (Wheaton, 
332 224193-01). The cultures were grown at $37^{\circ} \mathrm{C}$ and $200 \mathrm{rpm}$ to generate hypoxic conditions.

333 Oxygen levels were qualitatively monitored using methylene blue.

334 Carbon starvation cultures were prepared using log phase cells $\left(\mathrm{OD}_{600}=0.8\right)$ grown in rich

335

336

337

338

339

340

341

342

343

344

345

346

347

medium. Cultures were rinsed with carbon starvation medium (Middlebrook 7H9 supplemented with $5 \mathrm{~g} \cdot \mathrm{L}^{-1}$ bovine serum albumin fraction $\mathrm{V}, 0.85 \mathrm{~g} \cdot \mathrm{L}^{-1} \mathrm{NaCl}, 3 \mathrm{mg} \cdot \mathrm{L}^{-1}$ catalase and $0.05 \%$ Tyloxapol) and centrifuged for $5 \mathrm{~min}$ at $3,214 \mathrm{x}$ g at $4^{\circ} \mathrm{C}$. After three rinses, the pelleted cells were resuspended in carbon starvation medium to an $\mathrm{OD}_{600}=0.8$ and incubated at $200 \mathrm{rpm}$ and $37^{\circ} \mathrm{C}$.

\section{RNA extraction and determination of mRNA stability}

Biological triplicate cultures were treated with rifampicin (RIF) to a final concentration of 150 $\mu \mathrm{g} \cdot \mathrm{mL}^{-1}$ to halt transcription and RNA was extracted at various time points thereafter. For exponentially growing cells in normoxia and cells in carbon starvation, $7 \mathrm{~mL}$ samples $\left(\mathrm{OD}_{600}\right.$ 0.8) were collected per replicate and time point after blocking transcription. Samples and were snap-frozen in liquid nitrogen. For hypoxic samples, degassed RIF was injected using a 30G needle, and all samples were sacrificially collected per time point and replicate $\left(7 \mathrm{~mL}, \mathrm{OD}_{600}\right.$ 0.8) and snap-frozen in liquid nitrogen within 6 seconds of unsealing the bottles. Time points were taken at different intervals after adding RIF depending on the experiment.

Samples were stored at $-80^{\circ} \mathrm{C}$ and thawed on ice immediately before RNA extraction. Cells were centrifuged for $5 \mathrm{~min}$ at $3,214 \mathrm{x}$ g at $4^{\circ} \mathrm{C}$, and supernatants removed completely. Working on ice, the pellet was resuspended in $1 \mathrm{~mL}$ of TRIzol (Invitrogen), transferred to $2 \mathrm{~mL}$ disruption tubes (OPS Diagnostics $100 \mu \mathrm{m}$ zirconium lysing matrix, molecular grade) for cell lysis using a FastPrep-24 5G (MP) with 3 cycles of $7 \mathrm{~m} \cdot \mathrm{s}^{-1}$ for $30 \mathrm{~s}$, with $2 \mathrm{~min}$ on ice after each cycle. 300 
$354 \mu \mathrm{L}$ chloroform was added to each sample, mixed and centrifuged for $15 \mathrm{~min}$ at 21,130 x g and 4

$355{ }^{\circ} \mathrm{C}$. RNA was recovered from the aqueous layer and purified after DNase digestion in-column

356 using the Direct-zol RNA MiniPrep kit according to the manufacturer's instructions. A

357 NanoDrop 2000c (Thermo) was used to determine RNA concentrations and 1\% agarose gels

358 were used to verify RNA integrity.

359 For cDNA synthesis, $600 \mathrm{ng}$ of total RNA were mixed with $0.83 \mu \mathrm{L} 100 \mathrm{mM}$ tris $\mathrm{pH} 7.5$ and 
377 Translation was halted in normoxia and hypoxia cultures by chloramphenicol at a final

378 concentration of $150 \mu \mathrm{g} \cdot \mathrm{mL}^{-1} .1 \mathrm{~min}$ after adding chloramphenicol, rifampicin was added, and 379 time point samples were collected starting 1 min afterwards.

380 Re-aeration experiments were done using hypoxia cultures 18 hours after the sealing. Briefly, 381 each bottle was opened and the contents transferred to a $50 \mathrm{~mL}$ conical tube. Rifampicin was 382 added either 1 min before (transcription inhibition during hypoxia) or 2 min after opening the 383 bottles (transcription inhibition after re-aeration). Samples were taken 2, 7, 12, 17, and $32 \mathrm{~min}$ 384 after opening the bottles and snap-frozen in liquid nitrogen as described before. Samples were 385 collected in triplicate, steps prior to freezing were performed at $37^{\circ} \mathrm{C}$, and incubation of the 386 samples in either container was done at $200 \mathrm{rpm}$.

\section{Construction of 6xHis-3xFLAG tagged chromosomal RNase E M. smegmatis strain}

388 The RNase E-tagged strain (SS-M_0296) was built using a two-step process. Plasmid pSS250 was derived from pJM1 (78) and contained $1 \mathrm{~kb}$ of the sequence upstream and downstream of

390 the rne (msmeg_4626) start codon, with the sequence coding for the 6xHis-3xFLAG-TEV-4xGly

391 linker inserted after the start codon of rne. Constructs were built using NEBuilder HiFi DNA

392 Assembly Master Mix kit (E2621). Integrants were selected based on $\mathrm{Hyg}^{\mathrm{R}}\left(200 \mu \mathrm{g} \cdot \mathrm{mL}^{-1}\right.$

393 hygromycin) and confirmed by sequencing. Counter-selection with $15 \%$ sucrose was followed 394 by PCR screening to identify isolates that subsequently underwent second crossovers resulting in 395 loss of the plasmid and retention of the rne-FLAG-tagged sequence. 


\section{Construction of c-Myc tagged Helicase and PNPase strains}

398 The PNPase-tagged strain (SS-M_0412) was built by inserting a second copy of pnp

399 (msmeg_2656) with an N-terminal c-Myc-4xGly-linker along with its predicted native promoter

400 and 5' UTR at the Giles phage integration site (plasmid pSS282) into strain SS-M_0296. The

401 RNA helicase-tagged strain (SS-M_0416) was constructed in a similar way but using a C-

402 terminal 4xGly-linker-c-Myc tag on msmeg_1930 (plasmid pSS285).

\section{Alteration of intracellular ATP with bedaquiline and isoniazid}

Cells were grown as described before to an $\mathrm{OD}_{600}$ of $\sim 1.0$, rinsed two times in Minimal Media

405 Acetate wash (final concentrations are $0.5 \mathrm{~g} \cdot \mathrm{L}^{-1} \mathrm{~L}$-asparagine, $1 \mathrm{~g} \cdot \mathrm{L}^{-1} \mathrm{KH}_{2} \mathrm{PO}_{4}, 2.5 \mathrm{~g} \cdot \mathrm{L}^{-1}$ $\mathrm{Na}_{2} \mathrm{HPO}_{4}, 0.5 \mathrm{~g} \cdot \mathrm{L}^{-1} \mathrm{MgSO}_{4} \cdot 7 \mathrm{H}_{2} \mathrm{O}, 0.5 \mathrm{mg} \cdot \mathrm{L}^{-1} \mathrm{CaCl}_{2}, 0.1 \mathrm{mg} \cdot \mathrm{L}^{-1} \mathrm{ZnSO}_{4}, 0.1 \% \mathrm{CH}_{3} \mathrm{COONa}$,

$407 \quad 0.05 \%$ tyloxapol, $\mathrm{pH} 7.5$ ) using 5 min centrifugation steps at $3,214 \mathrm{x} \mathrm{g}$ and $4^{\circ} \mathrm{C}$, and finally

409 Acetate wash $+50 \mathrm{mg} \cdot \mathrm{L}^{-1}$ ferric ammonium citrate) at an $\mathrm{OD}_{600}=0.07$. The cells were then grown

410 for 24 hours at $37^{\circ} \mathrm{C}$ and $200 \mathrm{rpm}$ to an $\mathrm{OD}_{600}$ of $\sim 0.8$. To remove the high amounts of

411 extracellular ATP, 30 minutes before drug treatment the cells were rinsed in pre-warmed

412 Minimal Media Acetate wash as described before, resuspended in pre-warmed MMA, and

413 returned to the incubator. Either bedaquiline (BDQ), isoniazid (INH) or their vehicles were

414 added to the cell cultures to a final concentration of $5 \mu \mathrm{g} \cdot \mathrm{mL}^{-1}$ or $500 \mu \mathrm{g} \cdot \mathrm{mL}^{-1}$, respectively.

415 Cultures were incubated as described before, and samples were taken 30 min after adding BDQ,

416 or $6.5 \mathrm{~h}$ after adding INH for half-life-estimation and ATP-determination assays.

417 For half-life measurements, samples for BDQ were taken 0, 3, 6, 9, 12, 15 and 21 min after

418 adding RIF. Samples for INH were taken 0, 4, 8 and 12 min after adding RIF. All samples were 
collected in triplicates. RNA extraction for cultures in MMA was performed as indicated before with the following modifications: cell disruption was performed using $2 \mathrm{~mL}$ tubes prefilled with

421 Lysing Matrix B (MP) and 3 cycles of $10 \mathrm{~m} \cdot \mathrm{s}^{-1}$ for $40 \mathrm{~s}$; RNA was recovered from the aqueous

422 layer by isopropanol precipitation and resuspension in RNase-free $\mathrm{H}_{2} \mathrm{O}$; samples were treated

423 with $5 \mathrm{U}$ of TURBO ${ }^{\mathrm{TM}}$ DNase (Ambion) in presence of $80 \mathrm{U}$ of RNase Inhibitor, Murine (NEB)

424 for 1 hour at $37^{\circ} \mathrm{C}$ and under agitation. RNA was purification with an RNeasy Mini Kit (Qiagen)

425 according to the manufacturer's specifications.

\section{Intracellular ATP estimation}

427 ATP was estimated using the BacTiter-Glo kit (Promega). For BDQ or INH treatments in MMA, 428 after the treatment periods stated above, $1 \mathrm{~mL}$ of culture was pelleted at $\sim 21^{\circ} \mathrm{C}$ for $1 \mathrm{~min}$ at $42921,130 \mathrm{x}$. The supernatant was removed and the cells were resuspended in $1 \mathrm{~mL}$ of pre-warmed

430 MMA containing either BDQ, INH or the vehicle to match the prior treatment condition.

431 Immediately after, $20 \mu \mathrm{L}$ samples were transferred to a white 384 -well plate (Greiner bio-one)

432 containing $80 \mu \mathrm{L}$ of the BacTiter-Glo reagent and mixed for 5 minutes at room temperature.

433 Luminescence was measured in a VICTOR ${ }^{3}$ plate reader (PerkinElmer) (intracellular ATP). We 434 included controls for the supernatant collected (extracellular ATP), media + drug/vehicle 435 (background), and freshly made ATP standards for each reading.

436 To estimate the intracellular ATP in normoxia and hypoxia Middlebrook $7 \mathrm{H} 9$ cultures, $20 \mu \mathrm{L}$ 437 samples were collected at $37^{\circ} \mathrm{C}$ and immediately combined with the reagent to measure total 438 ATP (intracellular + extracellular). From the same cultures, $1 \mathrm{~mL}$ samples were syringe-filtered 439 (PES $0.2 \mu \mathrm{m})$ and the filtrate combined with the reagent to measure extracellular ATP. 440 Luminescence was measured as described above. Intracellular ATP was calculated by 
441 subtracting the extracellular ATP values from the total ATP values. Hypoxia samples were

442 sacrificially harvested per time point/replicate and combined with the reagent in $<6$ seconds. The

443 respective controls and ATP standards were also included for each reading. All samples were

444 measured in biological triplicate, and in at least two independent experiments.

445

AUTHOR CONTRIBUTIONS

DVB and SSS conceived and design the experiments. DVB and YZ performed the experiments. and SSS wrote the manuscript.

\section{ACKNOWLEDGEMENTS}

This work was supported by NSF CAREER award 1652756 to SSS. DVB was partially supported

by the LASPAU Fulbright Foreign Student Program. We thank all members of the Shell lab for

454 technical assistance and helpful discussions. The thank Dr. Christina Stallings, Dr. Jeremy Rock

455 and Dr. Sarah Fortune for generously providing strains.

\section{References}

1. Via LE, Lin PL, Ray SM, Carrillo J, Allen SS, Eum SY, Taylor K, Klein E, Manjunatha U, Gonzales J, Lee EG, Park SK, Raleigh JA, Cho SN, McMurray DN, Flynn JL, Barry CE, 3rd. 2008. Tuberculous granulomas are hypoxic in guinea pigs, rabbits, and nonhuman primates. Infect Immun 76:233340.

2. Belton M, Brilha S, Manavaki R, Mauri F, Nijran K, Hong YT, Patel NH, Dembek M, Tezera L, Green J, Moores R, Aigbirhio F, Al-Nahhas A, Fryer TD, Elkington PT, Friedland JS. 2016. Hypoxia and tissue destruction in pulmonary TB. Thorax 71:1145-1153. 
472

473

474

475

476

477

478

479

480

481

482

483

484

485

486

487

488

489

490

491

492

493

494

495

496

497

498

499

500

501

502

503

504

505

506

507

508

509

510

511

512

513
3. Rustad TR, Minch KJ, Brabant W, Winkler JK, Reiss DJ, Baliga NS, Sherman DR. 2013. Global analysis of mRNA stability in Mycobacterium tuberculosis. Nucleic Acids Res 41:509-17.

4. Albertson MH, Nyström T, Kjelleberg S. 1990. Functional mRNA half-lives in the marine Vibrio sp. S14 during starvation and recovery. Microbiology 136:2195-2199.

5. Georgellis D, Barlow T, Arvidson S, von Gabain A. 1993. Retarded RNA turnover in Escherichia coli: a means of maintaining gene expression during anaerobiosis. Mol Microbiol 9:375-81.

6. Sakamoto T, Bryant DA. 1997. Temperature-regulated mRNA accumulation and stabilization for fatty acid desaturase genes in the cyanobacterium Synechococcus sp. strain PCC 7002. Mol Microbiol 23:1281-92.

7. Thorne SH, Williams HD. 1997. Adaptation to nutrient starvation in Rhizobium leguminosarum bv. phaseoli: analysis of survival, stress resistance, and changes in macromolecular synthesis during entry to and exit from stationary phase. J Bacteriol 179:6894-901.

8. Redon E, Loubiere P, Cocaign-Bousquet M. 2005. Role of mRNA stability during genome-wide adaptation of Lactococcus lactis to carbon starvation. J Biol Chem 280:36380-5.

9. Anderson KL, Roberts C, Disz T, Vonstein V, Hwang K, Overbeek R, Olson PD, Projan SJ, Dunman PM. 2006. Characterization of the Staphylococcus aureus heat shock, cold shock, stringent, and SOS responses and their effects on log-phase mRNA turnover. J Bacteriol 188:6739-56.

10. Dressaire C, Picard F, Redon E, Loubiere P, Queinnec I, Girbal L, Cocaign-Bousquet M. 2013. Role of mRNA stability during bacterial adaptation. PLoS One 8:e59059.

11. Esquerre T, Laguerre S, Turlan C, Carpousis AJ, Girbal L, Cocaign-Bousquet M. 2014. Dual role of transcription and transcript stability in the regulation of gene expression in Escherichia coli cells cultured on glucose at different growth rates. Nucleic Acids Res 42:2460-72.

12. Chen H, Shiroguchi K, Ge H, Xie XS. 2015. Genome-wide study of mRNA degradation and transcript elongation in Escherichia coli. Mol Syst Biol 11:781.

13. Ignatov DV, Salina EG, Fursov MV, Skvortsov TA, Azhikina TL, Kaprelyants AS. 2015. Dormant non-culturable Mycobacterium tuberculosis retains stable low-abundant mRNA. BMC Genomics 16:954.

14. Tomcsanyi T, Apirion D. 1985. Processing enzyme ribonuclease E specifically cleaves RNA I. An inhibitor of primer formation in plasmid DNA synthesis. J Mol Biol 185:713-20.

15. Bouvet P, Belasco JG. 1992. Control of RNase E-mediated RNA degradation by 5'-terminal base pairing in E. coli. Nature 360:488-91.

16. McDowall KJ, Lin-Chao S, Cohen SN. 1994. A+U content rather than a particular nucleotide order determines the specificity of RNase E cleavage. J Biol Chem 269:10790-6. 
17. Apirion D, Gitelman DR. 1980. Decay of RNA in RNA processing mutants of Escherichia coli. Mol Gen Genet 177:339-43.

18. Donovan WP, Kushner SR. 1986. Polynucleotide phosphorylase and ribonuclease II are required for cell viability and mRNA turnover in Escherichia coli K-12. Proc Natl Acad Sci U S A 83:120-4.

19. Py B, Causton H, Mudd EA, Higgins CF. 1994. A protein complex mediating mRNA degradation in Escherichia coli. Mol Microbiol 14:717-29.

20. Miczak A, Kaberdin VR, Wei CL, Lin-Chao S. 1996. Proteins associated with RNase $E$ in a multicomponent ribonucleolytic complex. Proc Natl Acad Sci U S A 93:3865-9.

21. Py B, Higgins CF, Krisch HM, Carpousis AJ. 1996. A DEAD-box RNA helicase in the Escherichia coli RNA degradosome. Nature 381:169-72.

22. Grunberg-Manago M. 1999. Messenger RNA stability and its role in control of gene expression in bacteria and phages. Annu Rev Genet 33:193-227.

23. Carpousis AJ, Van Houwe G, Ehretsmann C, Krisch HM. 1994. Copurification of E. coli RNAase E and PNPase: evidence for a specific association between two enzymes important in RNA processing and degradation. Cell 76:889-900.

24. Vanzo NF, Li YS, Py B, Blum E, Higgins CF, Raynal LC, Krisch HM, Carpousis AJ. 1998. Ribonuclease E organizes the protein interactions in the Escherichia coli RNA degradosome. Genes Dev 12:2770-81.

25. Ait-Bara S, Carpousis AJ. 2010. Characterization of the RNA degradosome of Pseudoalteromonas haloplanktis: conservation of the RNase E-RhIB interaction in the gammaproteobacteria. J Bacteriol 192:5413-23.

26. Commichau FM, Rothe FM, Herzberg C, Wagner E, Hellwig D, Lehnik-Habrink M, Hammer E, Volker U, Stulke J. 2009. Novel activities of glycolytic enzymes in Bacillus subtilis: interactions with essential proteins involved in mRNA processing. Mol Cell Proteomics 8:1350-60.

27. Roux CM, DeMuth JP, Dunman PM. 2011. Characterization of components of the Staphylococcus aureus mRNA degradosome holoenzyme-like complex. J Bacteriol 193:5520-6.

28. Redko Y, Aubert S, Stachowicz A, Lenormand P, Namane A, Darfeuille F, Thibonnier M, De Reuse H. 2013. A minimal bacterial RNase J-based degradosome is associated with translating ribosomes. Nucleic Acids Res 41:288-301.

29. Kovacs L, Csanadi A, Megyeri K, Kaberdin VR, Miczak A. 2005. Mycobacterial RNase E-associated proteins. Microbiol Immunol 49:1003-7.

30. Csanadi A, Faludi I, Miczak A. 2009. MSMEG_4626 ribonuclease from Mycobacterium smegmatis. Mol Biol Rep 36:2341-4. 
31. Tamura M, Moore CJ, Cohen SN. 2013. Nutrient dependence of RNase E essentiality in Escherichia coli. J Bacteriol 195:1133-41.

32. Prud'homme-Genereux A, Beran RK, lost I, Ramey CS, Mackie GA, Simons RW. 2004. Physical and functional interactions among RNase $\mathrm{E}$, polynucleotide phosphorylase and the cold-shock protein, CsdA: evidence for a 'cold shock degradosome'. Mol Microbiol 54:1409-21.

33. Regonesi ME, Del Favero M, Basilico F, Briani F, Benazzi L, Tortora P, Mauri P, Deho G. 2006. Analysis of the Escherichia coli RNA degradosome composition by a proteomic approach. Biochimie 88:151-61.

34. Chen C, Deutscher MP. 2005. Elevation of RNase R in response to multiple stress conditions. J Biol Chem 280:34393-6.

35. Chen C, Deutscher MP. 2010. RNase R is a highly unstable protein regulated by growth phase and stress. RNA 16:667-72.

36. Kim KS, Manasherob R, Cohen SN. 2008. YmdB: a stress-responsive ribonuclease-binding regulator of E. coli RNase III activity. Genes Dev 22:3497-508.

37. Schubert OT, Ludwig C, Kogadeeva M, Zimmermann M, Rosenberger G, Gengenbacher M, Gillet LC, Collins BC, Rost HL, Kaufmann SH, Sauer U, Aebersold R. 2015. Absolute Proteome Composition and Dynamics during Dormancy and Resuscitation of Mycobacterium tuberculosis. Cell Host Microbe 18:96-108.

38. Gao J, Lee K, Zhao M, Qiu J, Zhan X, Saxena A, Moore CJ, Cohen SN, Georgiou G. 2006. Differential modulation of $\mathrm{E}$. coli mRNA abundance by inhibitory proteins that alter the composition of the degradosome. Mol Microbiol 61:394-406.

39. Iost I, Guillerez J, Dreyfus M. 1992. Bacteriophage T7 RNA polymerase travels far ahead of ribosomes in vivo. J Bacteriol 174:619-22.

40. Gatewood ML, Jones GH. 2010. (p)ppGpp inhibits polynucleotide phosphorylase from streptomyces but not from Escherichia coli and increases the stability of bulk mRNA in Streptomyces coelicolor. J Bacteriol 192:4275-80.

41. Siculella L, Damiano F, di Summa R, Tredici SM, Alduina R, Gnoni GV, Alifano P. 2010. Guanosine 5'-diphosphate 3'-diphosphate (ppGpp) as a negative modulator of polynucleotide phosphorylase activity in a 'rare' actinomycete. Mol Microbiol 77:716-29.

42. Battesti A, Bouveret E. 2006. Acyl carrier protein/SpoT interaction, the switch linking SpoTdependent stress response to fatty acid metabolism. Mol Microbiol 62:1048-63.

43. Frederix M, Downie AJ. 2011. Quorum sensing: regulating the regulators. Adv Microb Physiol 58:23-80. 
44. Atkinson GC, Tenson T, Hauryliuk V. 2011. The RelA/SpoT homolog (RSH) superfamily: distribution and functional evolution of ppGpp synthetases and hydrolases across the tree of life. PLoS One 6:e23479.

45. Corrigan RM, Bellows LE, Wood A, Grundling A. 2016. ppGpp negatively impacts ribosome assembly affecting growth and antimicrobial tolerance in Gram-positive bacteria. Proc Natl Acad Sci U S A 113:E1710-9.

46. Gentry DR, Hernandez VJ, Nguyen LH, Jensen DB, Cashel M. 1993. Synthesis of the stationaryphase sigma factor sigma $s$ is positively regulated by ppGpp. J Bacteriol 175:7982-9.

47. Chakraburtty R, Bibb M. 1997. The ppGpp synthetase gene (relA) of Streptomyces coelicolor $A 3(2)$ plays a conditional role in antibiotic production and morphological differentiation. J Bacteriol 179:5854-61.

48. Martinez-Costa OH, Fernandez-Moreno MA, Malpartida F. 1998. The relA/spoT-homologous gene in Streptomyces coelicolor encodes both ribosome-dependent (p)ppGpp-synthesizing and degrading activities. J Bacteriol 180:4123-32.

49. Artsimovitch I, Patlan V, Sekine S, Vassylyeva MN, Hosaka T, Ochi K, Yokoyama S, Vassylyev DG. 2004. Structural basis for transcription regulation by alarmone ppGpp. Cell 117:299-310.

50. Avarbock D, Avarbock A, Rubin H. 2000. Differential regulation of opposing RelMtb activities by the aminoacylation state of a tRNA.ribosome.mRNA.ReIMtb complex. Biochemistry 39:11640-8.

51. Bernstein JA, Khodursky AB, Lin PH, Lin-Chao S, Cohen SN. 2002. Global analysis of mRNA decay and abundance in Escherichia coli at single-gene resolution using two-color fluorescent DNA microarrays. Proc Natl Acad Sci U S A 99:9697-702.

52. Nouaille S, Mondeil S, Finoux AL, Moulis C, Girbal L, Cocaign-Bousquet M. 2017. The stability of an $m R N A$ is influenced by its concentration: a potential physical mechanism to regulate gene expression. Nucleic Acids Res 45:11711-11724.

53. Russell JH, Keiler KC. 2009. Subcellular localization of a bacterial regulatory RNA. Proc Natl Acad Sci U S A 106:16405-9.

54. Bayas CA, Wang J, Lee MK, Schrader JM, Shapiro L, Moerner WE. 2018. Spatial organization and dynamics of RNase E and ribosomes in Caulobacter crescentus. Proc Natl Acad Sci U S A 115:E3712-E3721.

55. Wayne LG, Hayes LG. 1996. An in vitro model for sequential study of shiftdown of Mycobacterium tuberculosis through two stages of nonreplicating persistence. Infect Immun 64:2062-9.

56. Weiss LA, Stallings CL. 2013. Essential roles for Mycobacterium tuberculosis Rel beyond the production of (p)ppGpp. J Bacteriol 195:5629-38. 
57. Dahl JL, Arora K, Boshoff HI, Whiteford DC, Pacheco SA, Walsh OJ, Lau-Bonilla D, Davis WB, Garza AG. 2005. The relA homolog of Mycobacterium smegmatis affects cell appearance, viability, and gene expression. J Bacteriol 187:2439-47.

58. Rock JM, Hopkins FF, Chavez A, Diallo M, Chase MR, Gerrick ER, Pritchard JR, Church GM, Rubin EJ, Sassetti CM, Schnappinger D, Fortune SM. 2017. Programmable transcriptional repression in mycobacteria using an orthogonal CRISPR interference platform. Nat Microbiol 2:16274.

59. Wolfe AD, Hahn FE. 1965. Mode of Action of Chloramphenicol. Ix. Effects of Chloramphenicol Upon a Ribosomal Amino Acid Polymerization System and Its Binding to Bacterial Ribosome. Biochim Biophys Acta 95:146-55.

60. Yukioka M, Morisawa S. 1971. Enhancement of the phenylalanyl-oligonucleotide binding to the peptidyl recognition center of ribosomal peptidyltransferase and inhibition of the chloramphenicol binding to ribosomes. Biochim Biophys Acta 254:304-15.

61. Drainas D, Kalpaxis DL, Coutsogeorgopoulos C. 1987. Inhibition of ribosomal peptidyltransferase by chloramphenicol. Kinetic studies. Eur J Biochem 164:53-8.

62. Lopez PJ, Marchand I, Yarchuk O, Dreyfus M. 1998. Translation inhibitors stabilize Escherichia coli mRNAs independently of ribosome protection. Proc Natl Acad Sci U S A 95:6067-72.

63. Chan LY, Mugler CF, Heinrich S, Vallotton P, Weis K. 2018. Non-invasive measurement of mRNA decay reveals translation initiation as the major determinant of mRNA stability. Elife 7.

64. Lakshmanan M, Xavier AS. 2013. Bedaquiline - The first ATP synthase inhibitor against multi drug resistant tuberculosis. J Young Pharm 5:112-5.

65. Shetty A, Dick T. 2018. Mycobacterial Cell Wall Synthesis Inhibitors Cause Lethal ATP Burst. Front Microbiol 9:1898.

66. Rao SP, Alonso S, Rand L, Dick T, Pethe K. 2008. The protonmotive force is required for maintaining ATP homeostasis and viability of hypoxic, nonreplicating Mycobacterium tuberculosis. Proc Natl Acad Sci U S A 105:11945-50.

67. Eoh H, Rhee KY. 2013. Multifunctional essentiality of succinate metabolism in adaptation to hypoxia in Mycobacterium tuberculosis. Proc Natl Acad Sci U S A 110:6554-9.

68. Smith T, Wolff KA, Nguyen L. 2013. Molecular biology of drug resistance in Mycobacterium tuberculosis. Curr Top Microbiol Immunol 374:53-80.

69. Kim JH, O'Brien KM, Sharma R, Boshoff HI, Rehren G, Chakraborty S, Wallach JB, Monteleone M, Wilson DJ, Aldrich CC, Barry CE, 3rd, Rhee KY, Ehrt S, Schnappinger D. 2013. A genetic strategy to identify targets for the development of drugs that prevent bacterial persistence. Proc Natl Acad Sci U S A 110:19095-100. 
70. Deb C, Lee CM, Dubey VS, Daniel J, Abomoelak B, Sirakova TD, Pawar S, Rogers L, Kolattukudy PE. 2009. A novel in vitro multiple-stress dormancy model for Mycobacterium tuberculosis generates a lipid-loaded, drug-tolerant, dormant pathogen. PLoS One 4:e6077.

71. Martini MC, Zhou Y, Sun H, Shell SS. 2019. Defining the transcriptional and post-transcriptional landscapes of Mycobacterium smegmatis in aerobic growth and hypoxia. Frontiers in Microbiology 10:591.

72. Fan H, Conn AB, Williams PB, Diggs S, Hahm J, Gamper HB, Jr., Hou YM, O'Leary SE, Wang Y, Blaha GM. 2017. Transcription-translation coupling: direct interactions of RNA polymerase with ribosomes and ribosomal subunits. Nucleic Acids Res 45:11043-11055.

73. Zhang Y, Mooney RA, Grass JA, Sivaramakrishnan P, Herman C, Landick R, Wang JD. 2014. DksA guards elongating RNA polymerase against ribosome-stalling-induced arrest. Mol Cell 53:766-78.

74. Miller OL, Jr., Hamkalo BA, Thomas CA, Jr. 1970. Visualization of bacterial genes in action. Science 169:392-5.

75. Burmann BM, Schweimer K, Luo X, Wahl MC, Stitt BL, Gottesman ME, Rosch P. 2010. A NusE:NusG complex links transcription and translation. Science 328:501-4.

76. Proshkin S, Rahmouni AR, Mironov A, Nudler E. 2010. Cooperation between translating ribosomes and RNA polymerase in transcription elongation. Science 328:504-8.

77. Esquerre T, Moisan A, Chiapello H, Arike L, Vilu R, Gaspin C, Cocaign-Bousquet M, Girbal L. 2015. Genome-wide investigation of mRNA lifetime determinants in Escherichia coli cells cultured at different growth rates. BMC Genomics 16:275.

78. Farrow MF, Rubin EJ. 2008. Function of a mycobacterial major facilitator superfamily pump requires a membrane-associated lipoprotein. J Bacteriol 190:1783-91.

79. Snapper SB, Melton RE, Mustafa S, Kieser T, Jacobs WR, Jr. 1990. Isolation and characterization of efficient plasmid transformation mutants of Mycobacterium smegmatis. Mol Microbiol 4:1911-9. 

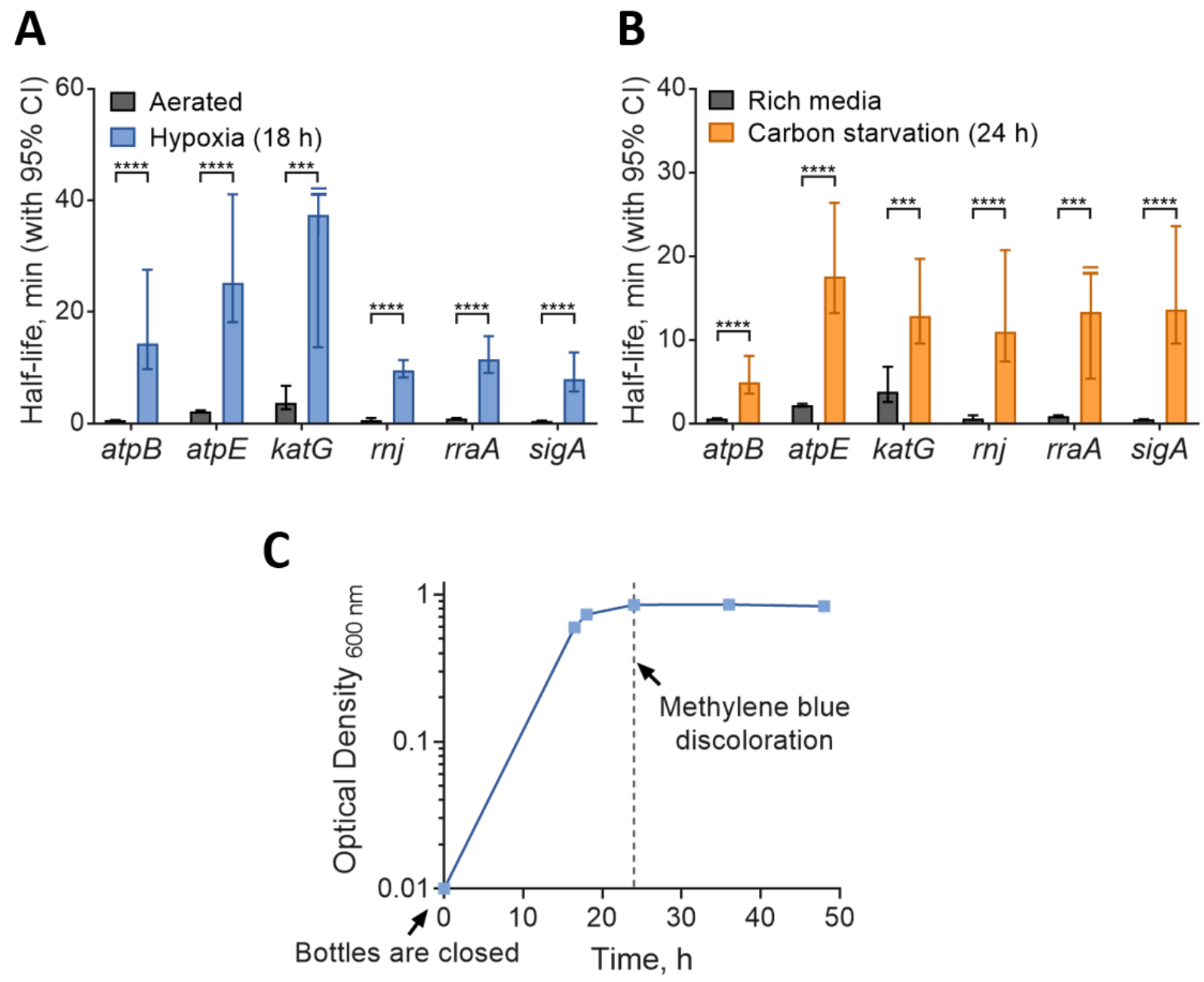

Figure 1

Transcript half-lives are increased in response to hypoxia and carbon starvation stress. Transcript half-lives for the indicated genes were measured for M. smegmatis mc $^{2} 155$ after blocking transcription with $150 \mu \mathrm{g} \cdot \mathrm{mL}^{-1} \mathrm{RIF}$. RNA samples were collected (A) during log phase normoxia, and hypoxia (18 hours after closing the bottles); or (B) during log phase in $7 \mathrm{H} 9$ supplemented with ADC, glycerol, and Tween 80 (rich media) or 7H9 with Tyloxapol only (carbon starvation, 24 hours). Degradation rates were compared using linear regression $(n=3)$, and half-lives were determined by the reciprocal of the best-fit slope. Error bars: $95 \% \mathrm{CI}$. *** $p<0.001 ; * * * * p<0.0001$. When a slope of zero was included in the $95 \% \mathrm{CI}$ (indicating no degradation), the upper limit for half-life was unbounded, indicated by a clipped error bar with a double line. (C) Growth kinetics for M. smegmatis under hypoxia using a variation of the Wayne model (55), showing OD stabilization at 18-24 hours. Oxygen depletion was assessed qualitatively by methylene blue discoloration. 

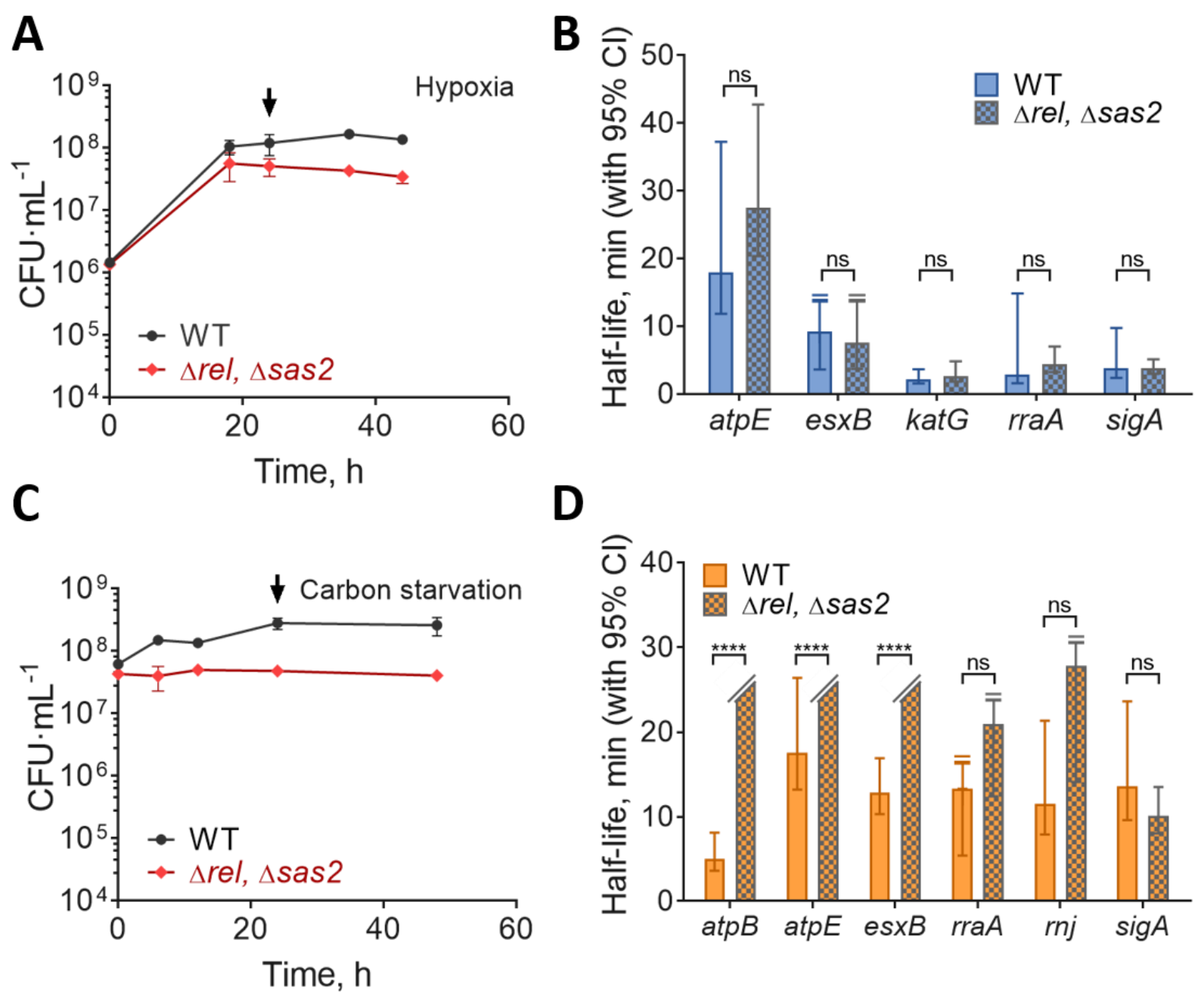

D

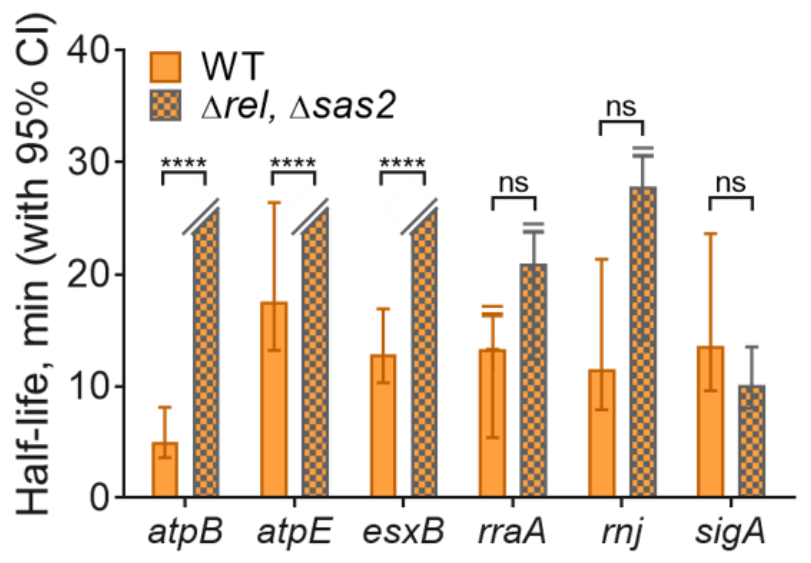

Figure 2

Transcript stabilization in hypoxia and carbon starvation is not dependent on the stringent response. (A) Growth kinetics for M. smegmatis $\mathrm{mc}^{2} 155$ (WT) and $\Delta$ rel, $\Delta$ sas 2 strains cultured in 7H9 in flasks sealed at time 0. (B) Transcript half-lives for a set of genes 24 hours after sealing the hypoxia bottles (arrow in A). RNA samples were collected after blocking transcription with $150 \mu \mathrm{g} \cdot \mathrm{mL}^{-1}$ RIF. (C) Bacteria were grown to log phase in $7 \mathrm{H} 9$ supplemented with ADC, glycerol, and Tween 80, then transferred to $7 \mathrm{H} 9$ supplemented with Tyloxapol only at time 0. (D) Transcript stability for a set of genes 22 hours after transfer to carbon starvation media (arrow in C). In A and C, the mean and SD of triplicate cultures is shown. In B and D, half-lives were compared using linear regression analysis $(n=3)$. Error bars: $95 \%$ CI. **** $p<0.0001$, n.s. $p>0.05$. In cases where no degradation was observed or when the upper $95 \%$ CI limit was unbounded, the bar or upper error bar were clipped, respectively. 
A

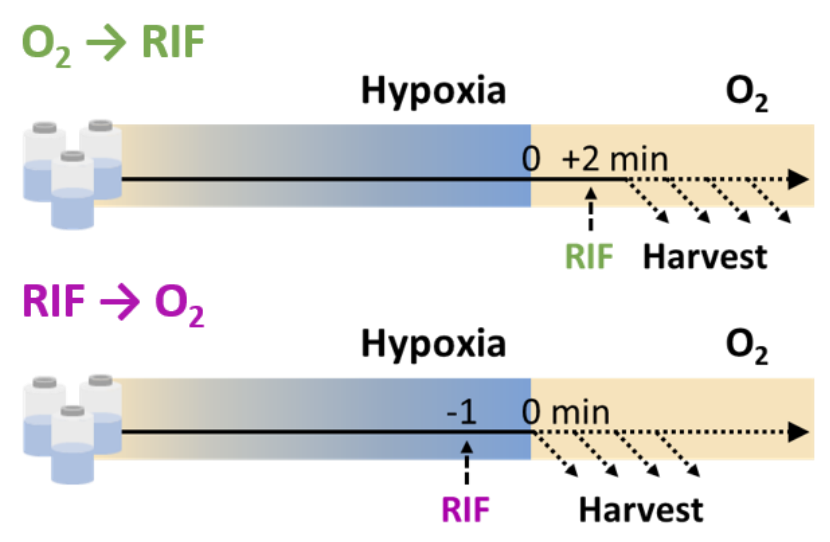

B
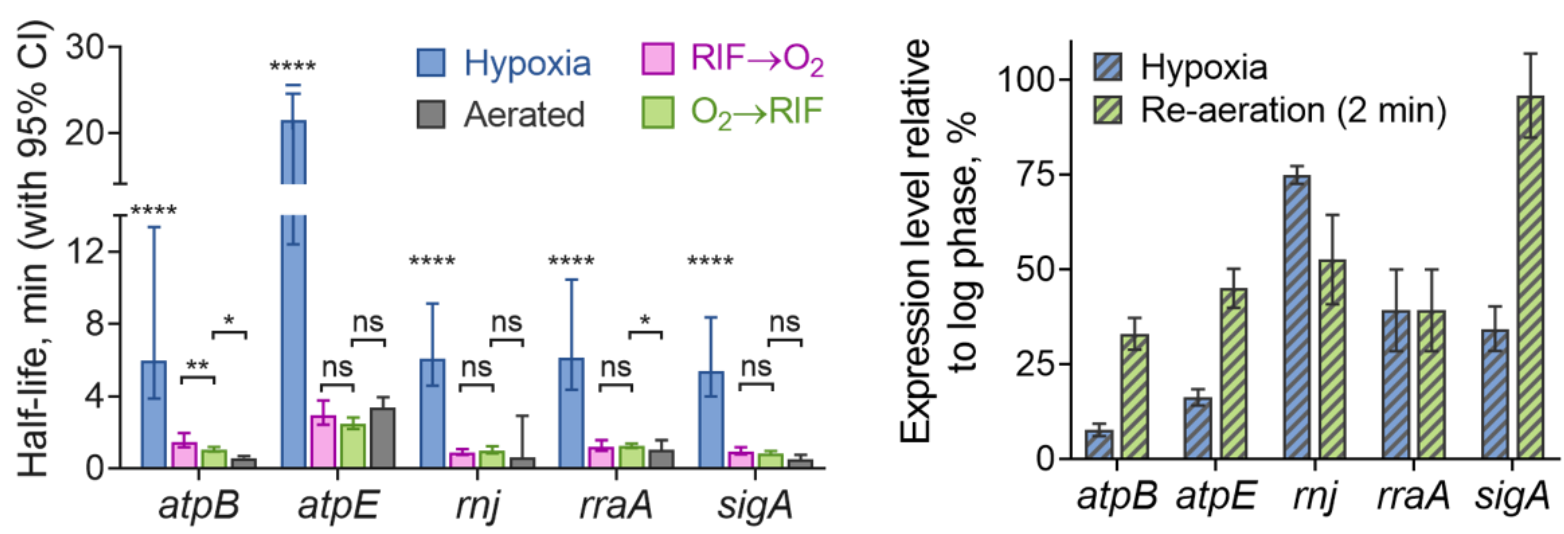

D

E
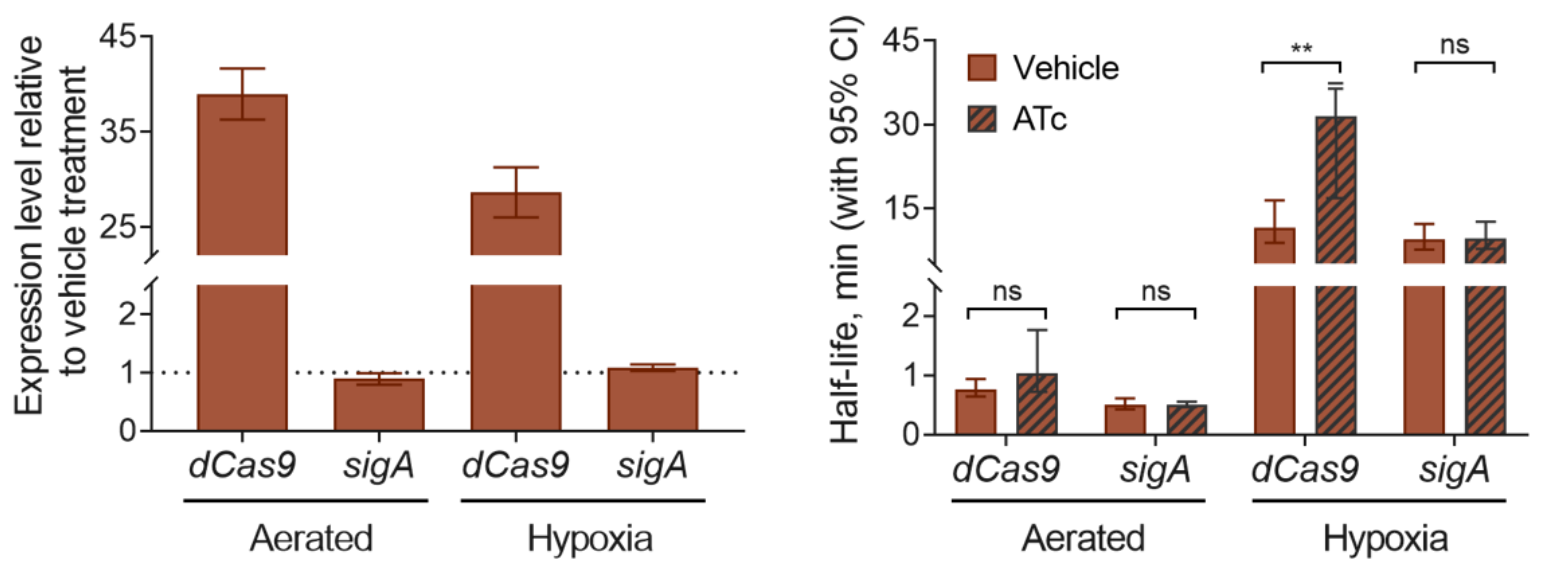

Figure 3

Hypoxia-induced mRNA stability is reversible and independent of mRNA abundance. (A) $M$. smegmatis was sealed in vials for 18 hours to produce a hypoxic environment, then reexposed to oxygen for two minutes before transcription was inhibited RIF (top) or injected with RIF one minute prior to opening the vials and re-exposing to oxygen (bottom). (B) Transcript 
771 half-lives for a set of genes are displayed for log phase normoxia cultures, hypoxia (18 h), and

772 re-aeration with RIF added either before or after opening the vials. Half-lives were compared by

773 linear regression analysis $(n=3)$. (C) Expression levels of transcripts in hypoxia (18 h) or $2 \mathrm{~min}$

774 re-aeration relative to the expression levels in log phase normoxia cultures (percentage). Error

775 bars: SD. (D) Expression levels of transcripts in hypoxia (18 h) or log phase normoxia after

776 being treated with $200 \mathrm{ng} \cdot \mathrm{mL}^{-1}$ ATc for $1 \mathrm{~h}$ or $10 \mathrm{~min}$, respectively, to induce $d$ Cas 9

777 overexpression, relative to the expression levels in a $\mathrm{H}_{2} \mathrm{O}$ vehicle treatment (percentage). Error

778 bars: SD. (E) Transcript half-lives for $d \operatorname{Cas} 9$ and $\operatorname{sig} A$ for $\log$ phase normoxia and hypoxia $(18 \mathrm{~h})$

779 after induction of $d$ Cas 9 with ATc or vehicle treatment as shown in D. In B and E, degradation

780 rates were compared using linear regression $(n=3)$, and half-lives were determined by the

781 reciprocal of the best-fit slope. Error bars: $95 \%$ CI. $* p<0.05, * * p<0.01, * * * * p<0.0001$, n.s.

$782 p>0.05$.

783 
A

RNase E RNA helicase (msmeg_1930)

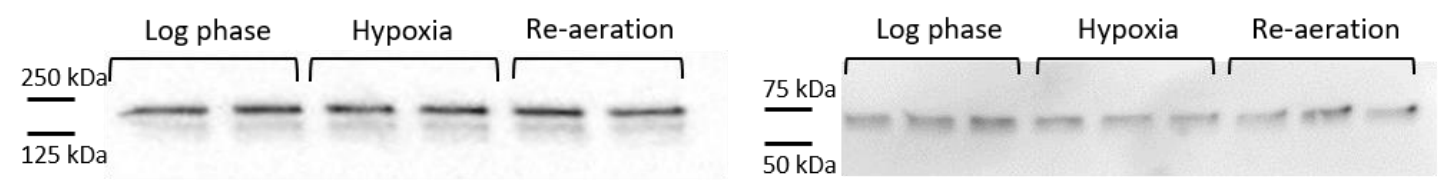

PNPase

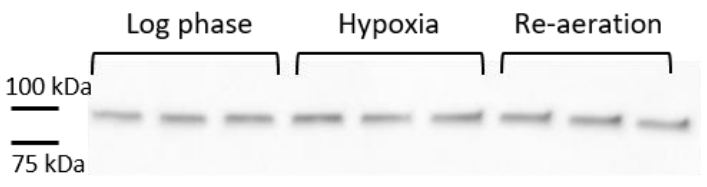

B

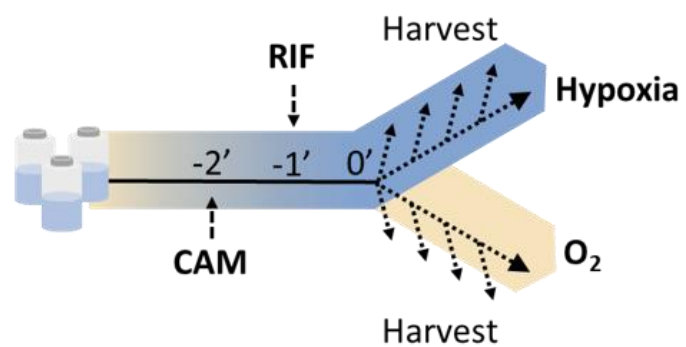

\section{C}

Figure 4 in M. smegmatis in log phase normoxia, hypoxia $(18 \mathrm{~h})$, and $2 \mathrm{~min}$ re-aeration. Samples were normalized to total protein level, which were similar on a per-OD basis in all conditions. (B) Translation was inhibited in hypoxic cultures by $150 \mu \mathrm{g} \cdot \mathrm{mL}^{-1}$ CAM $1 \mathrm{~min}$ before adding 150 $\mu \mathrm{g} \cdot \mathrm{mL}^{-1} \mathrm{RIF}$. RNA was harvested at time points beginning 2 min after adding CAM. (C) Transcript half-lives for samples from hypoxic cultures with the drug vehicle (ethanol), hypoxic cultures after translation inhibition, and 2 min re-aeration after translation inhibition. Degradation rates were compared using linear regression $(n=3)$, and half-lives were determined by the reciprocal of the best-fit slope. Error bars: $95 \%$ CI. n.s., $p>0.05, * p<0.05$, $* * * p<0.001$, 
A

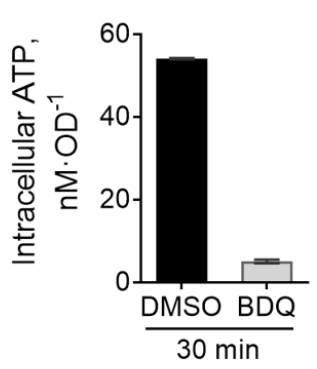

D

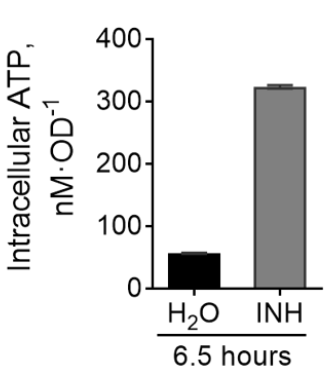

G

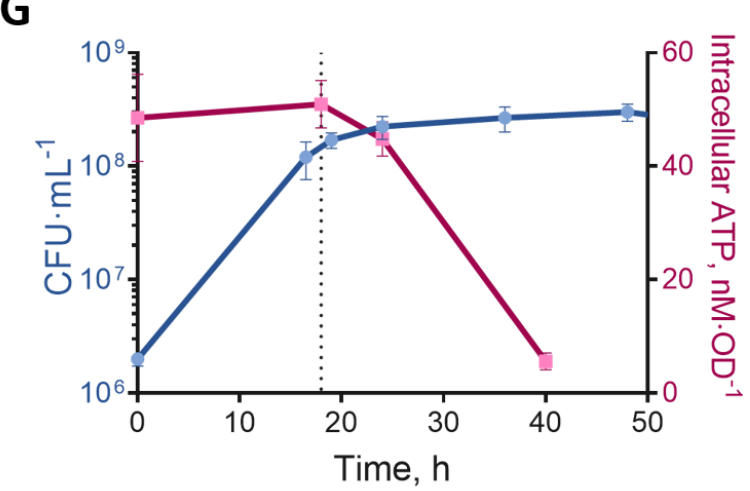

B

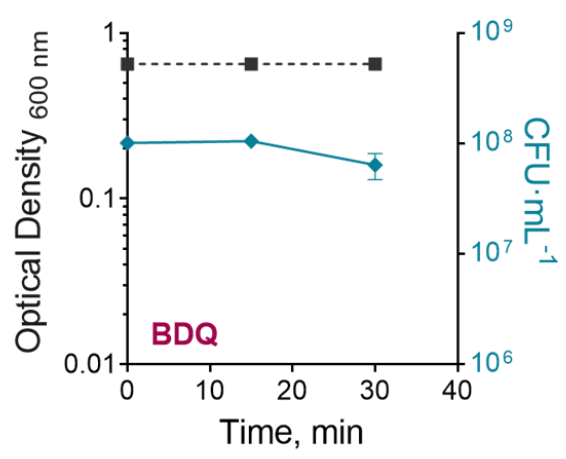

$\mathbf{E}$

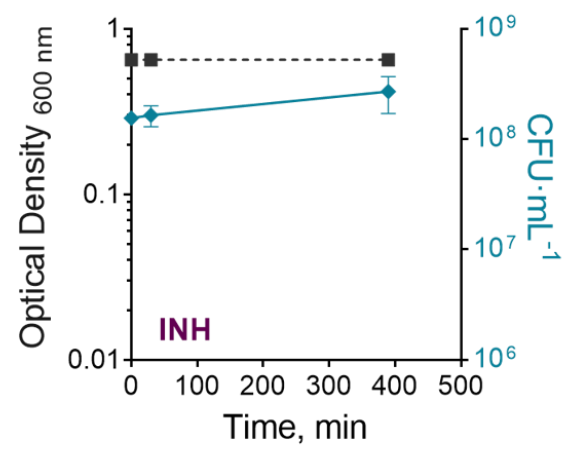

C

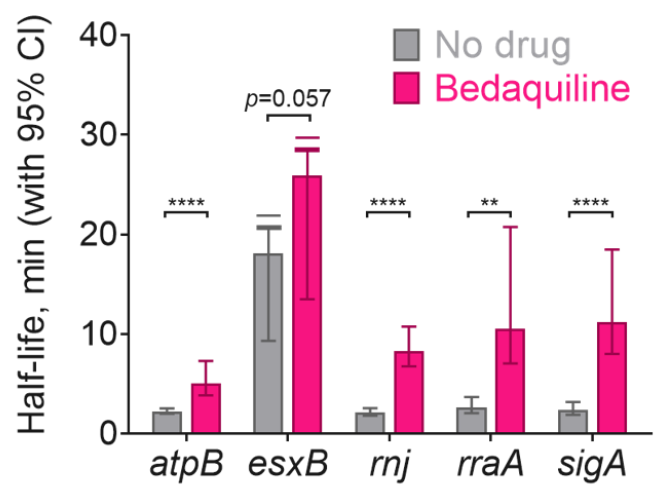

$\mathbf{F}$

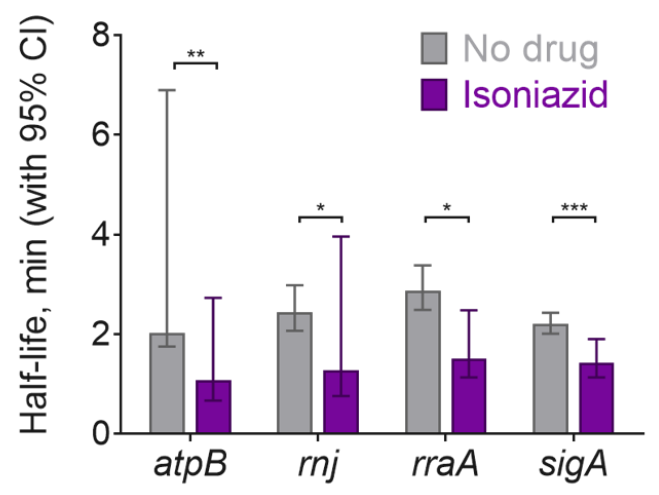

799

800

801

802

803

804

805

806

807

808

809

FIG 5

mRNA stability is modulated in response to changes in metabolic status. (A) M. smegmatis was cultured in MMA media for 22 hours to $\mathrm{OD}_{600} 0.8$ before being treated with $5 \mu \mathrm{g} \cdot \mathrm{mL}^{-1} \mathrm{BDQ}$ or the vehicle (DMSO) for $30 \mathrm{~min}$. Intracellular ATP was determined using the BacTiter-Glo kit. (B) Growth kinetics for M. smegmatis from panel A in presence of BDQ. (C) Transcript halflives for a sub-set of transcripts collected during intracellular ATP depletion (30 min with BDQ) or at the basal levels (30 min with DMSO). (D) As in panel A, but for M. smegmatis treated with $500 \mu \mathrm{g} \cdot \mathrm{mL}^{-1} \mathrm{INH}$ or the vehicle $\left(\mathrm{H}_{2} \mathrm{O}\right)$ for 6.5 hours. (E) Growth kinetics for $M$. smegmatis from panel D in presence of INH. (F) Transcript half-lives for a sub-set of transcripts after $6.5 \mathrm{~h}$ of INH or vehicle treatment. (G) Growth kinetics for $M$. smegmatis transitioning into hypoxia, and 
810 intracellular ATP levels at different stages. The dotted line represents the time at which transcript

811 stability analysis were made for the hypoxia $(18 \mathrm{~h})$ condition for Figures $1-4$. In $\mathrm{C}$ and F, half-

812 lives were compared using linear regression analysis $(n=3)$. Error bars: $95 \%$ CI. $* p<0.05$, **

$813 p<0.01, * * * p<0.001, * * * * p<0.0001$.

814

815

TABLES

TABLE 1

817 Strains used and sources

\begin{tabular}{|c|c|c|}
\hline Strain & Characteristics & Reference or source \\
\hline$m c^{2} 155$ & M. smegmatis, WT & $(79)$ \\
\hline SS-M_0296 & $\begin{array}{l}\left.\mathrm{mc}^{2} 155 \text { in which the native copy of RNase E ( } r n e\right) \text { is } \\
\text { N-terminally tagged with 6xHis-3xFLAG-TEV- } \\
4 x \text { Gly linker } \\
\text { (CACCACCACCACCACCACGATTACAAGGAT } \\
\text { CACGATGGCGATTACAAGGATCATGACATC } \\
\text { GACTATAAGGACGATGACGATAAGGAGAAC } \\
\text { CTGTACTTCCAGGGCGGCGGCGGC). }\end{array}$ & This work \\
\hline SS-M_0412 & $\begin{array}{l}\text { SS-M_0296 derivative containing a second copy of } \\
\text { PNPase (msmeg_2656) with its predicted native } \\
\text { promoter and 5' UTR, and N-terminally tagged with } \\
\text { c-Myc-4xGly-linker } \\
\text { (GAGCAGAAGCTGATCTCGGAAGAGGACCTC } \\
\text { GGCGGCGGCGGC) contained on Giles-integrating } \\
\text { plasmid pSS282 (Hyg }{ }^{\mathrm{R}} \text { ). }\end{array}$ & This work \\
\hline SS-M_0416 & $\begin{array}{l}\text { SS-M_0296 derivative containing a second copy of } \\
\text { RNA helicase (msmeg_1930) with its predicted } \\
\text { native promoter and 5' UTR, and C-terminally } \\
\text { tagged with 4x Gly linker-c-Myc } \\
\text { (GGCGGCGGCGGCGAGCAGAAGCTGATCTCG } \\
\text { GA) contained on a Giles-integrating plasmid } \\
\text { pSS285 }\left(\text { Hyg }^{\mathrm{R}}\right) \text {. }\end{array}$ & This work \\
\hline$\Delta r e l_{\mathrm{Msm}}$ & $\mathrm{mc}^{2} 155$ derivative, $\Delta r e l \Delta s a s 2$ & $(56)$ \\
\hline SS-M_0203 & $\begin{array}{l}\text { mc }^{2} 155 \text { derivative transformed with plasmid } \\
\text { pJR962, containing an ATc regulated } d \text { Cas } 9 .\end{array}$ & $(58)$ \\
\hline
\end{tabular}


821 Primers for qPCR

\begin{tabular}{|c|c|c|c|}
\hline Primer name & Gene & Directionality & Sequence $5^{\prime} \rightarrow 3$, \\
\hline SSS903 & atpB (msmeg_4942) & Forward & TGTTCGTGTTCGTCTGCTAC \\
\hline SSS904 & atpB (msmeg_4942) & Reverse & CGGCTTGGCGAGTTCTT \\
\hline SSS909 & atpE (msmeg_4941) & Forward & GGGTAACGCGCTGATCTC \\
\hline SSS910 & atpE (msmeg_4941) & Reverse & GAAGGCCAGGTTGATGAAGTA \\
\hline SSS1241 & $d \operatorname{Cas} 9$ & Forward & GACAAGTCGAAGTTCCTGATGTA \\
\hline SSS1242 & $d \operatorname{Cas} 9$ & Reverse & GATCTGCTTGTTCGGGTAGTT \\
\hline SSS537 & esxB (msmeg_0065) & Forward & GGTGAGGACACAGGGAAATAAG \\
\hline SSS538 & esxB (msmeg_0065) & Reverse & CGGAGATGCGCTCGAAAT \\
\hline SSS856 & katG (msmeg_6384) & Forward & GGCCCAATCAGCTCAATCT \\
\hline SSS857 & katG(msmeg_6384) & Reverse & CGGACCGGTAGTCGAAATC \\
\hline SSS706 & rnj (msmeg_2685) & Forward & TCATCCTCTCATCGGGTTTC \\
\hline SSS707 & rnj (msmeg_2685) & Reverse & TTCGCGCTCAACCTTCT \\
\hline SSS697 & rraA (msmeg_6439) & Forward & AACTACGGCGGCAAGAT \\
\hline SSS698 & rraA (msmeg_6439) & Reverse & GTCGAGAGGATCGACTTCAG \\
\hline JR273 (58) & sigA (msmeg_2758) & Forward & GACTACACCAAGGGCTACAAG \\
\hline JR274 (58) & sigA (msmeg_2758) & Reverse & TTGATCACCTCGACCATGTG \\
\hline
\end{tabular}

